\title{
Social Media: Online Modern Tool to Enhance Secondary Schools Students' Academic Performance
}

\author{
Busuyi Francis Olowo \\ Obafemi Awolowo University, Nigeria, olowo4404@gmail.com \\ Festus Oluwole Alabi \\ Adekunle Ajasin University, Nigeria \\ Comfort Abosede Okotoni \\ Obafemi Awolowo University, Nigeria \\ Musibau Adeoye Yusuf \\ Obafemi Awolowo University, Nigeria
}

\begin{abstract}
This paper reports a survey done that examined the relationship between the use of Facebook, WhatsApp, Twitter and YouTube on students' academic performance in secondary schools. The study adopted the descriptive research design. The population of the study comprised all 7,767 teachers in secondary schools. The sample of 385 teachers was randomly selected. Two instruments were used. The data were analyzed using Pearson Product Movement Correlation Statistics (PPMCS) at 0.05 level of significant. The findings showed that the use of Facebook, WhatsApp, Twitter, and YouTube were significantly related to students' academic performance of secondary schools. The study concluded that that the use of Facebook, WhatsApp, Twitter and YouTube among teachers and students had positive contributions to students' academic performance of secondary schools. The findings implicate that the teachers and students in secondary schools should admire the use of social medial such as Facebook WhatsApp, Twitter, and YouTube as an interactive forum for teachinglearning activities.
\end{abstract}

Keywords: Social media, Students’academic performance, Facebook, WhatsApp, Twitter, Youtube

\section{Introduction}

The goals of secondary schools education, in accordance with National Policy on Education (2014) are to prepare students for higher education and also prepare the students to be useful in the society they life. The attainment of these goals can be determined and measured through the performance of students in the secondary school most especially in their final examinations such as West Africa Examinations Council, National Examinations Council, National Business and Technical Examinations Board. The results from teachinglearning process could be accumulated to ability of the students to performed excellent in their academic and also useful to the society they life. That is why every nation, (Nwosu, 2008) including Nigeria earmarks huge budgetary allocations for it yearly. Similarly, parents and guardians contribute huge amount of money yearly toward their children's/wards' education. They acknowledge the education of their children as a worthwhile investment for future, social and economic security of their families and societies they live. Postlethwaite (2007) enumerated the factors that affect students' academic performance as school variable, environment/familyvariable and teachers-variables. Postlethwaite (2007) further emphasized that out of these factors, one that mostly influence the learning outcome are the teacher-variables, as these teachers are the ultimate implementer of the curriculum in the schools.

According to the literature, the teachers are the most crucial variables that influence the results of the learning process (Ausubel \& Robinson, 1981, as cited in Otilia, 2011; Hill, Bicer, \& Capraro, 2017; Hilton \& Canciello, 2018; Mwingirwa \& Miheso-O'Connor, 2016, Davis, Preston, \& Sahin, 2009a, 2009b). In the view of SaraviaShore (2008) teachers have the greatest impact on students' achievement since they have the most contact with students throughout the day. It can be deduced that the attainment of national objectives for the adequate preparation of students for their examinations and achievement of educational objectives could be attributed and depended largely on teachers. The teachers could be referred as the key in the entire education program and they could make or mar the best educational program in the world. The competent, commitment, passionate and 
professionally-qualified teachers could be seen as essential foundation for a good education system. Teacher could equally be seen as professional who imparts skills, knowledge, information and attitude, among others, to the learners. The passion of teacher is to see his/her students performed excellent in their both internal and external examinations.

However, empirical evidence showed that most secondary schools students' performance in Nigeria is generally poor. This has made educational stakeholders to doubt and lose confidence in the strategies and instructional delivering techniques of most of the teachers in Nigeria, most especially in Osun State. Evidence has been trace to the trend of academic performance of students in Osun State secondary schools. The records shown that the students that have five credits and above including English and mathematics in WASSCE 2012 was $22.21 \%, 2013$ was $20.54 \%, 2014$ was $18.55 \%, 2015$ was $21.68 \%, 2016$ was $46.3 \%$ and 2017 was $44.59 \%$ (WAEC, 2017). Looking at the external examination performance from 2012-2017, non above average level of $50 \%$. Above external examination records depict that instruction delivery process of the teachers is faulty and need to be addressed.

In this global era, social media tools are present in many areas of life. Social media are now one of the most significant and online tools that link people together all around the world to get information that are instructive and educative. A study conducted by Yu, Tian, Vogel, and Kwok (2010) reported that online discussions between students through social learning communities networked through an artifact, such as mobile learning communities clearly improved students' social connections; improved their self-esteem; and boosted their learning performance. The term "Social media" is defined as the application that allows users to converse and interact with each other; to create, edit and share new forms of textual, visual and audio content, and to categorize, label and recommend existing forms of content (Selwyn 2012). Junco and Chickering (2010) equally referred social media as a collection of Web sites, services, and activities that engage users through sharing, collaboration and democratization of roles and responsibilities. Cohen (2007) pointed out that social media sites can be used for educational purposes. Bouhnik and Deshen (2014) noted that social media networks have become a shared platform that enhances accessibility, encourages cooperation, and intensifies motivation to take an active part in learning. For the purpose of the study, social media simply refers as online platform where two more interact to exchange educative information. It equally means a platform where text, visual and audio content can be share between the teacher and the students for teaching-learning activities.

Tennyson (2010) noted that in the 1990s, the integration of the media artifact by the tutor or teacher in an e-learning system was the technological factor that improved online social interaction among group members in learning communities. Looking at the empirical studies that have been conducted, Talaue, AlSaad, AlRushaidan, AlHugail, AlFahhad (2018) investigated impact of social media on academic performance of selected college students. Study revealed that social media have impact on students' achievement. In same vain, Boateng and Afua (2016) carried out study on impact of social media on student academic life in higher education. The report of their study showed that social media was widely used by students of higher institution and those participants were in support of the idea that social media contributed a significant quota to the development of their academic life. This is an indication that nowadays the use of social media is crucial and imperative for students' academic performance.

Researches have shown that different studies have focused on the use of the social media sites and its impact on students' academic performance in the developed world (Choney, 2010; Enriquez, 2010; Hill \& Uribe-Florez, 2020; Khan, 2009; Karpinski \& Duberstein, 2009; Panaoura, 2017). It is doubted if such studies have been carried out in Nigeria secondary schools, most especially in Osun state. It is against this background that it has become necessary to conduct this research aimed at investigating the relationship between the uses of social media sites on students' academic performance among Osun state secondary schools.

\section{Social Media and Student Academic Performance}

The world has become a global village through internet accessibility. That is why different people connect to each other within and outside of each country. This strengths the communication ability and also improves accessibility to needed information timely. Today social media has been accepted as modern platform where people connect to create and share ideas, picture, video, and information. Boyd and Ellison (2007) regarded social network sites as public web-based services that enable users to develop a personal profile, read and react to postings made by other users on the site, identify with whom they have a connection and receive and send messages either publicly or privately. This definition made it clear that individuals may choose to send private messages, write on other user's walls, organize social activities, and keep informed about other user's daily 
activities. Shresthaet al. (2013) regarded social media as a way of connections among people in which they share, create, exchange ideas and information in virtual communities and network. Equally Asian (2010) described social media as a virtual place where people locate themselves to share vital and relevant information. For the purpose of this study, Social media is referred as an online location where different users can interact to share educative and informative messages to each other which would strength the users to be well informed and have ideas about current issues.

Today social media has been accepted by higher institution making it a platform where students connect with their instructors, fellow students and other higher authorities across the board. Lu and Churchill (2014) stated that the teacher plays a principal role in guiding students in online teaching. Their study showed that the social interaction that helps students share and construct knowledge that are achievable through the pertinent role of the tutor/teacher. A decrease in the frequency of interactive messages in online communities could be triggered when the online tutor or teacher is not present with the group in the online community. Tennyson (2010) disclosed that in the 1990s, the integration of the media artifact by the tutor or teacher in an e-learning system which was the technological factor that improved online social interaction among group members in learning communities. Social online interaction in online learning communities and its analysis became an important domain of research (Gok, 2015; Sahin \& Shelley; 2008; Tennyson, 2010; Wallace-Spurgin, 2019). A study conducted by Yu, Tian, Vogel, and Kwok (2010) reported that online discussions among students through social learning communities networked through an artifact, such as mobile learning communities, improved their selfesteem, clearly improved students' social connections and boosted their learning performance. In the same vein, Preston, Phillips, Gosper, McNeill, Woo, and Green (2010) found out that nearly most (70\%) of the students stated that they learnt in online learning communities such as Twitter chats, Facebook communities, WhatsApp groups, and Google+ communities just like as they do in lectures that are held in the classroom in the presence of other students. Embi (2012) recorded that the most recognized social media in Nigeria were Youtube, Twitter,2go, WhatsApp, Myspace, Skype, Facebook, Friendster, , Blackberry messenger and so on. The study purposely focused on Facebook, Tweeter, WhatsApp and Youtube.

\section{Facebook}

Facebook is a social networking website that was launched in February 2004 which is currently privately managed and operated by Facebook. According to Boyd, (2007), Facebook was founded by Mark Zuckerberg and others when he was a student at Harvard. Facebook was was restricted to Harvard students only when the site was initially launched but later extended to high school students. The site as now globally recognized and used by most people. Facebook is a social networking site and online communication tool that allows users to construct a public or private profile in order to connect and interact with people who are part of their extended social network. According to Godwin-Jones (2008), Facebook is a tools and platforms that useful to improve language learning, communication and human interaction. The study of Arteaga, Cortijo and Javed (2014) found out that adoption of Facebook had positive effects for the purposes of using it. This Facebook could be used as an educational tool as a useful resource for communication during teaching-learning process. Lenhart and Madden (2007) reported that $48 \%-50 \%$ of teenagers are active Facebook users. Ractham, Kaewkitipong and Firpo (2012) claimed that Facebook usage in the classroom is time consuming for tutors, yet their study concluded that it was useful to communicate frequently with students in order to maintain a high level of interest and activity in the overall learning environment.

Arrington (2005) reported that $85 \%$ of students adopted and use Facebook in their universities and colleges. Lenhart and Madden (2007) disclosed in their report that $48 \%-50 \%$ of teenagers were active social networking users. They further opined that Facebook's numerous features such as instant messaging, video, picture of posting and applications download supplement serve the educational function that allowed sharing, proper communication and collaboration between students and faculty. The study Mbodila, Ndebele and Muhandji (2014) inferred that the use of Facebook had significant contributions to student's collaboration and engagement

\section{WhatsApp}

WhatsApp is a mobile application used for instant messaging which has majorly replace the normal phone short messages (SMS) because of its capacity to send and receive large volume of messages and media files unlike the SMS. Historically, Fawzi (2015) disclosed that WhatsApp came into existence in the year 2009 by Brian Acton and Jan Koum. The site has become the most popular social media applications used by mostly the young people for communication. WhatsApp is usually installed from an apple store into smart or Google play store, 
window or android phones. It can also be accessed directly from web using the window PC or laptop. Once WhatsApp application is installed, users can then create their personal WhatsApp account which will be visible to other WhatsApp users in their phone contact lists upon synchronization. Users can start communication with people in their lists or invite new users to Whatsapp. WhatsApp therefore enable two people to chat and make video or voice call, and groups of people to make group chat using internet/Wi-Fi connection or data charges.

Bansal and Joshi (2014) reported that WhatsApp has become highly addictive which has created a great impact on regular users, especially the students. Bere (2013) investigated the use of WhatsApp in a South African university His study stated that the students gave the positive feedback and claimed that it was an easier way to communicate with their teachers and the rest of the class. Another study conducted by Amry (2014) revealed the effectiveness of WhatsApp social networking in comparison with face-to-face learning in the classroom. Researches have made it clear that WhatsApp has become an important aspect of students which has become a shared platform that enhances accessibility, encourages cooperation, and intensifies motivation to take an active part in academic assignments (Bansal \& Joshi, 2014; Bere, 2013). Etim, Idongesit and Ema (2016) conducted an investigation of WhatsApp utilization and academic performance of Geography students in Uyo, Akwa Ibom State. Their study revealed that there was a significant influence of WhatsApp module utilization on geography students' academic performance. In the same vein, Izyani and Mohamed (2016) carried out a study on perception of Malaysian students on WhatsApp utilization as learning material in English language classroom. Their study indicated that WhatsApp utilization was crucial because it enhanced students' proficiency in the use of English language and also helping the students to learn the language more.

\section{Twitter}

Twitter regarded as social network site that was established by Jack Dorsey in 2006 (Rodrigues, Sabino, \& Zhou, 2011). Twitter gained popularity because it offered more different options such as micro blogging and mostly used by some celebrities (Jasra, 2010). Twitter is considered an information network that connects users with topics and discussions that are important and meaningful to them. Each user can post informational "tweets" that consist of 140 characters in length or less using a computer or mobile device connected to the Internet and the Twitter network. Other Twitter users can follow the tweets of others to stay up-to-date on the information they post in their accounts. Twitter provides information that displays detailed information on specific tweets when desired by a Twitter user. In addition to short messages, users can share videos, Web links, photos and other media content. Twitter users who prefer to protect their tweets from public viewing usually makes their tweets exclusively available to those users to which they have explicitly given access Twitter platform is used to connect with friends, family, and acquaintances on an informal basis but the platform has been expanded to more formal users which included education sector. Fox and Varadarajan (2011) observed that research opportunities on the use of Twitter for educational purposes are still emerging. According to Davis (2010), Twitter platform provides teachers with the means to connect with other teachers around the world which can assist them to develop their globally accepted teaching-learning method. He further opined that Twitter has the potential to essentially transform the current face of today's educational system according and improving the way that teachers instruct their students. It means that use of twitter by teachers can enhance their teaching professional which would invariably affect their ability during teaching-learning process.

\section{YouTube}

YouTube is platform that majorly based on sharing of video which is customized uploaded by the users (Pinto, Almeida \& Gonçalves, 2013). Usually, the platform allows the users to keep track and manage a record of users that view the videos. Historically, YouTube was founded by Steve Chen, Jawed Karim and Chad Hurley in February 2005 (Graham, 2005). YouTube is currently most popular online video community where millions of people can share and watch originally-created videos. YouTube provides a forum for people to inform connect, and inspire others across the globe and acts as a major distribution platform for original content creators for viewer to see. YouTube is a modern mass medium commonly used in this new digital age. Cheng, Liu \& Dale (2013) considered videos on the channel as entertainment-based, meanwhile some researchers categorize the platform as broadly based with potentials for education and life-long learning. Kay (2012) gave a broad review of research on video podcasts to provide a framework for an educational approach to the new media. Duncan, Yarwood-Ross \& Haigh (2013) explained the importance and relevance of video sharing sites and argued that YouTube videos were valuable to practical, education, and research. Duffy (2008) opined YouTube could also be useful in the educational process by creating a learning community where everyone has a voice and practically understand the purpose of the video. By implementing YouTube into the 
educational process, teachers are providing students with a learning environment in which they can thrive through having access to practical and reality of the subject content.

To this end, researches reviewed shown that social media platforms are very significant, useful and contributed to the improvement of academic performance of students in secondary schools. However, Mingle and Adams (2015) investigated the participation of Ghana High schools students in social media network on their academic performances. Their study revealed that social media network participation negatively affected the students' academic performance.

\section{Objectives of Study}

The objectives of the study are to:

a) examine the relationship between the use of Facebook and students' academic performance in Osun State secondary schools

b) examine the relationship between the use of WhatsApp and students' academic performance in Osun State secondary schools

c) examine the relationship between the use of Twitter and students' academic performance in Osun State secondary schools

d) examine the relationship between the use of YouTube and students' academic performance in Osun State secondary schools.

\section{Research Hypothesis}

The following hypotheses were formulated to guide the study

1) $\mathrm{H}_{0}$ : There is no significant relationship between the use of Facebook and students' academic performance in Osun State secondary schools

2) $\mathrm{H}_{0}$ : There is no significant relationship between the use of WhatsApp and students' academic performance in Osun State secondary schools

3) $\mathrm{H}_{0 \text { : }}$ There is no significant relationship between the use of Twitter and students' academic performance in Osun State secondary schools

4) $\mathrm{H}_{0}$ : There is no significant relationship between the use of YouTube and students' academic performance in Osun State secondary schools

\section{Methodology}

The study adopted the descriptive research design. The population of the study comprised all 7,767 teachers in Osun State secondary schools. The sample comprised 385 teachers using Taro Yamane's formula to determine the sample size. The Taro Yamane's formula is $\mathrm{n}=\mathrm{N} /\left[1+\left(\mathrm{Ne}^{2}\right)\right]$ (where, $\mathrm{n}=$ Sample size $\mathrm{N}=$ Total population, e=0.05 (constant)) (Yamane, 1967). Simple random sampling technique was used to select seven Local Government Areas (L.G.As) from thirty local governments in Osun State. From each LGA, five secondary schools were selected, 11 teachers were selected from each school using simple random sampling technique. Two instruments were used. The first instrument was that titled 'Use of Social Media Platform and Students' Academic Performance Questionnaire (SMSAPQ)" which was used to gather relevant information from the respondents.

The questionnaire was divided into five sections. Section A gathered information on respondent's profiles. Section B contained six items that collected information on the use of Facebook among teachers and students, section $\mathrm{C}$ contained six items that collected information on the use of WhatsApp among teachers and students, section D contained five items that collected information on the use of Twitter among teachers and students while section D contained five items that collected information on the use of YouTube among teachers and students. The Inventory on Senior Secondary School Certificate Examination (SSCE) was used as second instrument to collect data on students' academic performance in the sampled schools. For SMSAPQ, 4-point Likert scale of Strongly Agree $(\mathrm{SA})=4$, Agree $(A)=3$, Disagree $(\mathrm{D})=2$ and Strongly Disagree $(\mathrm{SD}=1$ was used to rate section B C, D and F. Face and content validity of the first instrument was established by means of experts' review, and the test re-test method was adopted to achieve the Cronbach's Alpha reliability coefficient of 0.72 while the validity and reliability of the second instrument has already been established by WAEC body 
before the final results was released. The data collected was analyzed inferentially, using correlation statistics to analyze the four hypotheses. The hypothesis was tested at 0.05 level of significance.

\section{Findings and Discussion}

\section{Hypothesis 1: There is no significant relationship between the use of Facebook and students' academic performance Osun State secondary schools}

The study hypothesized that there is no significant relationship between the use of Facebook and students' academic performance in Osun State secondary schools. The statistical evidence from the table indicated that the null hypothesis was rejected because the P-value is less than the alpha value $(r=0.692$, $d f=2073 \& p<0.05)$. Therefore, there was significant relationship between the use of Facebook and students' academic performance in Osun State secondary schools (see Table 1). This indicated that the use of Facebook among the teachers and students positively enhanced the academic performance of the students. This is an indication that interaction of teachers and students through means of discussing subjects content, showing instructional aids of subject taught by teacher to students on the platform, giving notice of extra-classes and assignment contributed immensely to students' academic performance. It is therefore worthwhile for the teachers and students to know and use the social media as an interactive platform for teaching-learning activities. The finding concurred with the findings of Arteaga, Cortijo and Javed (2014) who found out that adoption of FaceBook has positive effects for the purposes of use. The study also agreed with the study of Mbodila, Ndebele, \& Muhandji (2014) inferred that the use of Facebook has a significant impact on student's collaboration and engagement.

Table 1. Pearson Product Moment Correlation Analysis for Relationship between the use of Facebook and Students' Academic Performance Osun State Secondary Schools

\begin{tabular}{lccccccc}
\hline Variables & N & Mean & SD & Df & R & P & Remark \\
\hline Use of Facebook & 380 & 22.91 & 5.32 & & & & $\begin{array}{c}\mathrm{H}_{0} \\
\text { Rejected }\end{array}$ \\
Students' Academic Performance & 1690 & 53.31 & 23.83 & & & & \\
\end{tabular}

\section{Hypothesis 2: There is no significant relationship between the use of WhatsApp and students' academic performance in Osun State secondary schools}

The Table 2 shows that there is significant relationship between the use of WhatsApp and students' academic performance in Osun State secondary schools. The stattical evident on the table depicts that the P-value is less than the alpha value $(\mathrm{r}=0.615, \mathrm{df}=2071 \& \mathrm{p}<0.05)$. Therefore, there was significant relationship between the use of WhatsApp and students' academic performance in Osun State secondary schools. This indicated that the use of WhatsApp platform among the teachers and students positively contributed to students' academic perfomance. This means that discussing more on the platform on subject taught in the class, allow students to ask questions with prompt answers on the platform, sending subject material to read, and giving students assignment on the platform positively attract and enhance the students ability to learn. It is therefore imperative for teachers and students to know that WhatsApp platform in an online platform for teaching-learning interaction. The study was in consonance with the study of Bere (2013) who claimed that WhatsApp was an easier way for a student to communicate with their teachers and the rest of the class. The study concurred with the findings of Ema (2016) who revealed that WhatsApp module utilization had positive significant influence on geography students' academic performance. The study equally concurred with the findings of Izyani and Mohamed (2016) who indicated that WhatsApp utilization enhanced students' proficiency in the use of English language and also helping the students to learn the language more.

Table 2. Pearson Product Moment Correlation Analysis for Relationship between the use of WhatsApp and Students' Academic Performance Osun State Secondary Schools

\begin{tabular}{lccccccc}
\hline Variables & N & Mean & SD & Df & R & P & Remark \\
\hline Use of WhatsApp & 380 & 23.32 & 5.72 & & & & $\begin{array}{c}\mathrm{H}_{0} \\
\text { Rejected }\end{array}$ \\
Students' Academic Performance & 1690 & 54.91 & 24.41 & & & & \\
\hline
\end{tabular}




\section{Hypothesis 3: There is no significant relationship between the use of Twitter and students' academic performance in Osun State secondary schools}

The Table 3 depicts that there is significant relationship between the use of Twetter and students' academic performance in Osun State secondary schools. Looking at the statistical evidence from the Table, the P-value is less than the alpha value $(r=0.542, \mathrm{df}=2071 \& \mathrm{p}<0.05)$. Therefore, there was significant relationship between the use of Twetter and students' academic performance in Osun State secondary schools. This indicated that the use of Twitter platform among the teachers and students positively improved student academic performance. This indicates that sharing of information of relevant topics of the subject content on the platform, giving notice of extra classes, giving extra assignment on the platform, and frequently twitting educating information by teachers to students positively contributed and motivated the willingness of students to learn more. It is therefore necessary to use Twitter as a means of communicating educative information and relevant from teachers to students. The study concurred with the findings of Davis (2010) who opined that Twitter has the potential to essentially transform the current face of today's educational system according and improving the way that teachers instruct students.

Table 3. Pearson Product Moment Correlation Analysis for Relationship between the use of Twitter and Students' Academic Performance in Osun State Secondary Schools

\begin{tabular}{lccccccc}
\hline & N & Mean & SD & Df & R & P & Remark \\
\hline Uariables & 380 & 23.32 & 5.72 & & & & \\
Students' Academic Performance & 1690 & 56.82 & 26.48 & 2071 & 0.542 & $\mathrm{p}<0.05$ & $\mathrm{H}_{0}$ \\
Rejected
\end{tabular}

\section{Hypothesis 4: There is no significant relationship between the use of YouTube and students' academic performance in Osun State secondary schools}

The Table 4 shows that there is significant relationship between the use of YouTube and students' academic performance in Osun State secondary schools. The statistical evidence from the Table shows that the P-value is less than the alpha value $(r=0.461, \mathrm{df}=2071 \& \mathrm{p}<0.05)$. This inferred that, there was significant relationship between the use of YouTube and students' academic performance in Osun State secondary schools. This implies that the use of YouTube positively contributed to academic performance of students. This is an indication that ability of the teachers to download video practical material as an teaching aid in the classroom, sending of online subject video to their students watch at their own time, and sending educative and informative video students to view can improve the students learning capacity. It is therefore relevant that teachers and students to visit YouTube for educative and informative video that can improve academic performance. The finding concurred with the study of Duncan, Yarwood-Ross \& Haigh (2013) who explained the importance of video sharing sites and argued that YouTube videos were valuable to practical, education, and research.

Table 4. Pearson Product Moment Correlation Analysis for Relationship between the use of YouTube and Students' Academic Performance in Osun State Secondary Schools

\begin{tabular}{|c|c|c|c|c|c|c|c|}
\hline Variables & $\mathbf{N}$ & Mean & SD & Df & $\mathbf{R}$ & $\mathbf{P}$ & Remark \\
\hline Use of Youtube & 380 & 25.32 & 5.71 & & & & $\mathrm{H}_{0}$ \\
\hline Students' Academic Performance & 1690 & 58.61 & 26.48 & 2071 & 0.461 & $\mathrm{p}<0.05$ & Rejected \\
\hline
\end{tabular}

The study finally concluded that social media such as Facebook, WhatsApp, Twitter and YouTube positively contributed to the academic performance of student. This makes it important that teachers and students should use social media as means for teaching-learning activities. The findings of the study against the findings of Mingle and Adams (2015) who revealed that social media network negatively affected the students' academic performance.

\section{Conclusions and Recommendations}

The use of the social media cannot be over-emphasized among the teachers and students in the secondary schools. The Social media such as Facebook WhatsApp, Twitter and YouTube have been accepted as modern online tool that can facilitate the students' academic performance. That is why it is imperative for teachers and 
students in the secondary schools to use the social media platform as a means of teaching-learning interactive forum. Therefore, teachers and students of Osun State secondary schools including other schools in Nigeria are expected to know that the social media platforms gives room for better academic performance, therefore, it advocates that they need to make use of social media platform as teaching-learning interactive forum. The findings implicate that the teachers and students should admire the use of social medial such as Facebook WhatsApp, Twitter and YouTube which would enable them to compete world-widely.

Base on the findings the study, the following recommendation were made: Teachers should see social media as means of disseminating relevant information to their students; the teachers should sensitize and trigger the interest of their students so that they can use the social media for the academic purposes; teachers should guide the students on proper way to use the social media so that the platform will not be used negatively; and teachers should always ensure that they disseminate only academic and educative information to the students on the social media platform.

\section{References}

Amry, A. B. (2014). The impact of WhatsApp mobile social learning on the achievement and attitudes of female students compared with face to face learning in the class room. European Scientific Journal, 10(22), 116-136.

Arrington, M. (2005). 85\% of college students use Facebook. TechCrunch. Retrieved on September 30, 2019 from http://www.techcrunch.com/2019/09/07/85-of-college-students-usefacebook/.

Arteaga, R., Cortijo, V., \& Javed, U. (2014). Students' perceptions of Facebook for academic purposes. Computers \& Education, 70, 138-149.

Bansal, T., \& Joshi, D. D. (2014). A study of students' experiences of mobile learning. Global Journal of Human-Social Science, 14(4), 26-33.

Barbieri, F., Ronzano, F., \& Saggion, H. (2016). What does this emoji mean? A vector space skipgram model for Twitter emojis. Proceedings of Language Resources and Evaluation Conference (3967-3972).

Bere, A. (2013). Using mobile instant messaging to leverage learner participation and transform pedagogy at a South African University of Technology. British Journal of Educational Technology, 44(4), 544561.

Boateng, R. O. \& Afua, A. A. (2016). The Impact of Social Media on Student Academic Life in Higher Education. Global Journal of Human-Social Science: G Linguistics \& Education, 16( 4), 1-7

Bouhnik, D., \& Deshen, M. (2014). WhatsApp goes to school: Mobile instant messaging between teachers and students. Journal of Information Technology Education, 13, 217-231.

Boyd, D. (2007). Social Network Sites: Definition, History, and Scholarship. Computer Mediated Communication, 3-20.

Boyd D., \& Ellison, N. (2007). Social network sites: Definition, history, and scholarship. Journal of Computer \& Mediated Communication, 13(1), 210-230

Cheng, X., Liu, J., \& Dale, C. (2013). Understanding the characteristics of internet short video sharing: A YouTube-based measurement study. IEEE Transactions on Multimedia, 15(5), 1184-1194

Choney, S. (2010) Facebook Use Can Lower Grades by 20 Percent, Study Says. Retrieved on 17 November, 2019 from http://www.msnbc.com/id/39038581/ns.technology_and_science-tech_and_gadgets/.

Davis, M. (2010). Social networking goes to school. Education Week, 111-116.

Davis, N., Preston, C., \& Sahin, I. (2009a). Training teachers to use new technologies impacts multiple ecologies: Evidence from a national initiative. British journal of educational technology, 40(5), 861878.

Davis, N., Preston, C., \& Sahin, I. (2009b). ICT teacher training: Evidence for multilevel evaluation from a national initiative. British Journal of Educational Technology, 40(1), 135-148.

Duffy, P. (2008). Engaging the YouTube Google-eyed generation: Strategies for using web 2.0 in teaching and learning. The Electronic Journal of eLearning, 6(2), 119-130.

Enriquez, J.G. (2010). Facebook and Other Online Social Networking Sites Can Lower Grades, Study Says. Retrieved on 17 November, 2019 from http://seerpress.com/facebook-and-other-online-socialnetworking-sites-can-lower-grades-studysays/6935/.

Etim, P. J., Udosen, I. N. \& Ema, I. B. (2016). Utilization of WhatsApp and students' performance in Geography in Uyo Educational Zone, Akwa Ibom State. International Journal of Innovation and Research in Educational Sciences, 3 (5), 2349-5219

Fawzi, H. A. (2015). Usage of WhatsApp application for e-learning and its impact on academic performance in Irbid National University in Jordan. International Journal of Applied Engineering, 10 (19), 3987539879. 
Federal Republic of Nigeria (2014). National Policy on Education. Nigerian Educational Research and Development Council. 6th ed. Lagos.

Godwin-Jones, R. (2008). Mobile computing technologies: Lighter, faster, smarter. Language Learning \& Technology, 12(3), 3-9

Gok, T. (2016). The effects of social networking sites on students' studying and habits. International Journal of Research in Education and Science (IJRES), 2(1), 85- 93.

Graham, Jefferson (2005). "Video websites pop up, invite postings. Retrieved on 17 November, 2019 from (http://usato day30.usatoday.com/tech/news/techinnovations/2005-11-21-video-websites_x.htm). USA Today. Gannett Company.

Hill, J.E. \& Uribe-Florez, L. (2020). Understanding secondary school teachers' TPACK and technology implementation in mathematics classrooms. International Journal of Technology in Education (IJTE), $3(1), 1-13$.

Hill, K.K., Bicer, A., \& Capraro, R.M. (2017). Effect of teachers' professional development from MathForward $^{\mathrm{TM}}$ on students' math achievement. International Journal of Research in Education and Science (IJRES), 3(1), 67-74.

Hilton, J.T. \& Canciello, J. (2018). A five-year reflection on ways in which the integration of mobile computing technology influences classroom instruction. International Journal of Technology in Education (IJTE), 1(1), 1-11.

Izyani, B. M. \& Mohamed, A. E. (2016) Students' perception on the use of WhatsApp as a learning tool in esl classroom. Journal of Education and Social Sciences, 4(1), 96-106.

Jasra, M. (2010). The History of Social Media [Infographic]. Retrieved on December 4, 2019, from Web Analytics World: http://www.webanalyticsworld.net/2010/11/history-ofsocial-media-infographic.html

Junco, R., Heibergert, G. \& Loken, E. (2010). The Effect of Twitter on college students Engagement and Grades. Journal of Computer Assisted Learning, 3(1), 1-14

Karpinski, A, C. \& Duberstein, A. (2009). A Description of Facebook Use and Academic Performance amongUndergraduate and Graduate Students. San Diego, California: American National Research Association. 4(2), 1- 19

Khan, U (2009). Facebook student underachieve in exams. Daily Telegraph, Retrieved on September, 2019, fromhttp://www.telegraph.co.uk/educationnews/5145243/Faceb ook-students-underachieve-inexams.html

Lenhart, A., \& Madden, M. (2007). Teens, privacy, \& online social networks. Pew Internet and American Life Project Report. Retrieved on $17 \quad$ November, 2019 from http://www.pewinternet.org/pdfs/PIP_Teens_Privacy_SNS_Report_Final.pdf

Mingle, J. and Adams, M. (2015) Social media network participation and academic performance in senior high schools in Ghana. Library Philosophy and Practice (ejournal). Paper 1286.

Lu, J. \& Churchill, D. (2014). Using social networking environments to support collaborative learning in a Chinese university class: Interaction pattern and influencing factors. Australasian Journal of Educational Technology, 30(4), 472-486.

Mbodila, M., Ndebele, C., \& Muhandji, K. (2014). The Effect of Social Media on Student's Engagement and Collaboration in Higher Education: A Case Study of the Use of Facebook at a South African University. Journal of Communication, 5(2), 115-125

Nwosu, C. (2008). Budget 2009: Nigeria proposes N2.87tn. Retrieved on 17 November, 2019 from http://www.haaba.com/news/ 2008/12/03/272-216382/ Budget2009-nigeria-proposes-n2.87tn

Otilia CLIPA (2011). Teacher perceptions on teacher evaluation: the purpose and the assessors within the assessment process. Procedia - Social and Behavioral Sciences, 29 (2011) 158 - 163

Panaoura, A. (2017). Parental involvement in developing students' perseverance in solving mathematical problem through the use of social media. International Journal of Technology in Education and Science (IJTES), 1(1), 36-47.

Pinto, H., Almeida, J. M., \& Gonçalves, M. A. (2013). Using early view patterns to predict the popularity of YouTube videos. In Proceedings of the sixth ACM international conference on Web search and data mining (pp. 365-374). ACM.

Postlethwaite, T. N. (2007). Evaluating teacher competence through the use of performance assessment task: An overview. Journal of Personnel Evaluation in Education, 5(1), 121-132.

Preston, G., Phillips, R., Gosper, M., McNeill, M., Woo, K., \& Green, D. (2010). Web-based lecture technologies: Highlighting the changing nature of teaching and learning. Australasian Journal of Educational Technology, 26(6), 717-728.

Sahin, I., \& Shelley, M. (2008). Considering students' perceptions: The distance education student satisfaction model. Journal of Educational Technology \& Society, 11(3), 216-223.

Saravia-Shore, M. (2008). Diverse teaching strategies for diverse learners. In R.W. Cole (Ed.), Educating everybody"s children: We know what we need to do. Alexandria, Va: ASCD. 
Selwyn, N. (2012). Social media in higher education. The Europa world of learning.

Talaue, G.M., AlSaad, A., AlRushaidan, N., AlHugail, A., AlFahhad, S. (2018). The impact of social media on academic performance of selected college students. International Journal of Advanced Information Technology (IJAIT), 8(4/5), 27-35

Wallace-Spurgin, M. (2019). Measuring student cognitive engagement when using technology. I. Sahin \& V. Akerson (Eds). ISTES Organization.

Yamane, T. (1967). Statistics: An Introductory Analysis, 2nd Ed., New York: Harper and Row.

YouTube. (2005). Wikipedia, The Free Encyclopedia. Retrieved November 1, 2019, from http://en.wikipedia.org/wiki/YouTube

Yu, A. Y., Tian, S. W., Vogel, D., \& Kwok, R. C. W. (2010). Can learning be virtually boosted? An investigation of online social networking impacts. Computers \& Education, 55(4), 1494-1503 